\title{
Development of planning index for evaluating climate change protocols: analysis of Mumbai Metropolitan Region's Regional Plan 1996-2011
}

\author{
Sonam Sahu ${ }^{*}$ and Izuru Saizen
}

\begin{abstract}
Conserving resources, harmonizing living standards, and employing energy efficient methods are potential solutions to climate change, which can be positively accomplished through development and planning. However, today, as the first world countries advance towards "positive development", some third world countries are developing in an "unwanted pattern". The metropolitan cities of developing countries attract most of the country's population, consequently becoming the worst sufferers of the situation. They grow faster than their capacity allows, and then due to the lack of strategy, poor governance, and weak policies; face overwhelming pressure on land and natural resources. Documenting this situation using the case of a metropolitan city in India, the present paper aims to identify the problems faced by a metropolitan city in a developing country. The Mumbai Metropolitan Region's Regional Plan 1996-2011 was analyzed to determine the response to climate change mitigation and adaptation. Furthermore, a new diagnostic tool, namely the "Climate Change Planning Index", which can deliver valuable information at a glance, was developed. The paper concludes with a summary of the climate change crisis and the necessity of development in a developing metropolitan city.
\end{abstract}

Keywords: Regional Planning, Urbanization, Climate Change Planning Index, Plan analysis

\section{Introduction}

Climate change planning, also known as Planning for Climate Change has emerged as a new mandate after the witnessing and predicting the consequences of climate change in the Earth's atmosphere (Davoudi et al. 2009, 2012; Füssel 2007; Measham et al. 2011; UN Habitat 2014). While there is a lot of agitation in the scientific community about climate change as a challenge, the research database of region specific climate change planning is still not strong enough. Many national and international organizations such as ICLEI's (Local Government for Sustainability), Energy Cities, C40 and many NGOs are currently promoting the introduction of

\footnotetext{
${ }^{*}$ Correspondence: ar.snmsahu@gmail.com

Laboratory of Regional Planning, Graduate School of Global

Environmental Studies, Kyoto University, 2nd Floor, Research Building No.

5, Yoshida-honmachi, Sakyo-ku, Kyoto 6068501, Japan
}

climate priorities in the planning of a city and are supporting local governments in this direction. However, planning codes and procedures differ depending on regional contexts. Therefore, it is impossible for climatologists and planners to reach one global solution to climate change crisis favorable to local governments of different regions (EPA 2016). The situation is worse for less developed countries, because the code and conduct of planning is liquidated by several factors such as poverty, dependence on climate-based resources, and low adaptive capacity (Parliamentary Office of Science and Technology: UK 2006). This can mostly be drawn from the fact that most of the countries which have a stringent planning system and lawful implementation of the planning policies have performed better in Greenhouse Gas (GHG) reduction goals; and these mostly happen to be the industrialized countries of the world. For example, London' has achieved a huge reduction in the emission 
levels, currently approximating to the 1990 level (The World Bank 2010); (Greater London Authority 2011); New York is seeing a significant drop in GHG emissions (York 2017); London, Ontario (City of London 2017) has achieved a reduction as low as $8 \%$ below the 1990 level while, Hoornweg et al. (2011) demonstrated graphically how Sweden and Germany have lowered down their per capita GHG emissions with policy changes. The World Bank (2011) recognises the impact that local planning governments have on emissions from the different planning sectors like land use planning, transportation etc.

For cities and towns in developed countries, adaptation is easier, because of the availability of finances and better technology. However, cities in less developed countries face multiple challenges (UN-Habitat 2014; World Bank 2010) and hence lie far behind in the March. Moreover, urbanization, which is being seen as catalyst for the climate related problems in the world is increasing exponentially in the developing counties. United Nations (2016) alleges that world's most populated urban cities are located in less developed countries, mostly in the global south and India is projected to add 404 million urban dwellers by 2050 to the world urban population (United Nations 2015a, b). United Nations (2016) introduced a list of megacities ${ }^{1}$ located in Global South, according to which, Delhi and Mumbai, two Indian cities lie on the second and forth platform in 2016 respectively while there are four more in the most populated 30 megacities. World Bank (2010) alleges that metropolitan cities, especially the coastal cities of the world, will be the most affected by climate change. This calls for a need to apply climate change protocols to the planning aspects of metropolitan cities of India at an urgent basis.

While planning is acknowledged as a solution to uncontrolled urbanization (Wahlgren et al. 2010; Taylor 2012); studies confirm the significant role of spatial planning in shaping the strengths and weaknesses of a region's future with respect to climate change (Antonson et al. 2016; Baettig et al. 2007; Biesbroek et al. 2009, 2010; Davoudi et al. 2009; Hamin and Gurran 2009; Wilson and Piper 2010). Roggema (2016) talked about the issues of urban regions due to climate uncertainties. Chang et al. (2014) proposed a Climate Change Index which indicated the degree of susceptibility of a region to climatic extremes. Boswell et al. (2012) have established in their book how embedding climate action plans in local plans has proven to be beneficial in US. In many researches, climate change planning has received attention (Baynham and Stevans 2012; Hurlimann and March 2012; KamalChaoui and Robert 2009) but even then, a universal tool

\footnotetext{
${ }^{1}$ Megacity: City with a population of more than 10 million people.
}

that fits all contexts has not been discovered. There is need of an application index that provides policy makers with a quick overview of region-specific sophisticated information in a précised form. Summarizing this situation, the paper aims to analyze the planning strategies of an urbanizing metropolitan city in a developing country and determine its response to climate change protocols. As such, the present paper attempts to study and discuss the following string of thoughts; how does a city vulnerable to climate change plans to cope with this challenge; how well the planning objectives of a city in a developing country are aligned with climate protocols; and with the growing need of economic development, how is the city balancing its climate related priorities. The Mumbai Metropolitan Region (MMR) in India is selected for the study. The paper evaluates the planning strategies by analyzing MMR's Regional Plan 1996-2016. A new tool, namely the Climate Change Planning Index, is developed to evaluate planning for mitigation and adaptation protocols. The results are expressed as sunburst graphs, which statistically demonstrate the potential of climate change mitigation and adaptation strategy present in the textual documents. The results of this study are important to the planners, climatologists and researchers as these provide a quick insight to the measure of strength and weakness of the planning system of MMR at a glance. In addition to this, the results show outright that which component of planning needs more efforts and has more scope of work. The study enhances the local knowledge of climate planning and can be a strong pillar for the future planning in MMR. It establishes the actual linkage between climate change protocols and planning policies of MMR and therefore can ensure the adherence of climate priorities in the planning process right at the beginning.

It is notable that, the new tool 'Climate Change Planning Index' is a flexible design which takes into account the planning textbooks of the city/region itself. Hence, by modifying the decision parameters as per the context, this tools can be applied to any region which has an established planning system.

For the context of this paper, the word planning implies 'spatial planning' and since the study area is a metropolitan region, which comprises of many districts and towns; spatial planning specifically refers to spatial planning of a regional i.e. regional planning.

\section{Methods and materials}

The study employed a rigorous methodology and exhaustive process of analysis described as follows:

1. Multiple field surveys were conducted in the MMR to understand the factors affecting the climate and discuss the land cover changes in the past. 


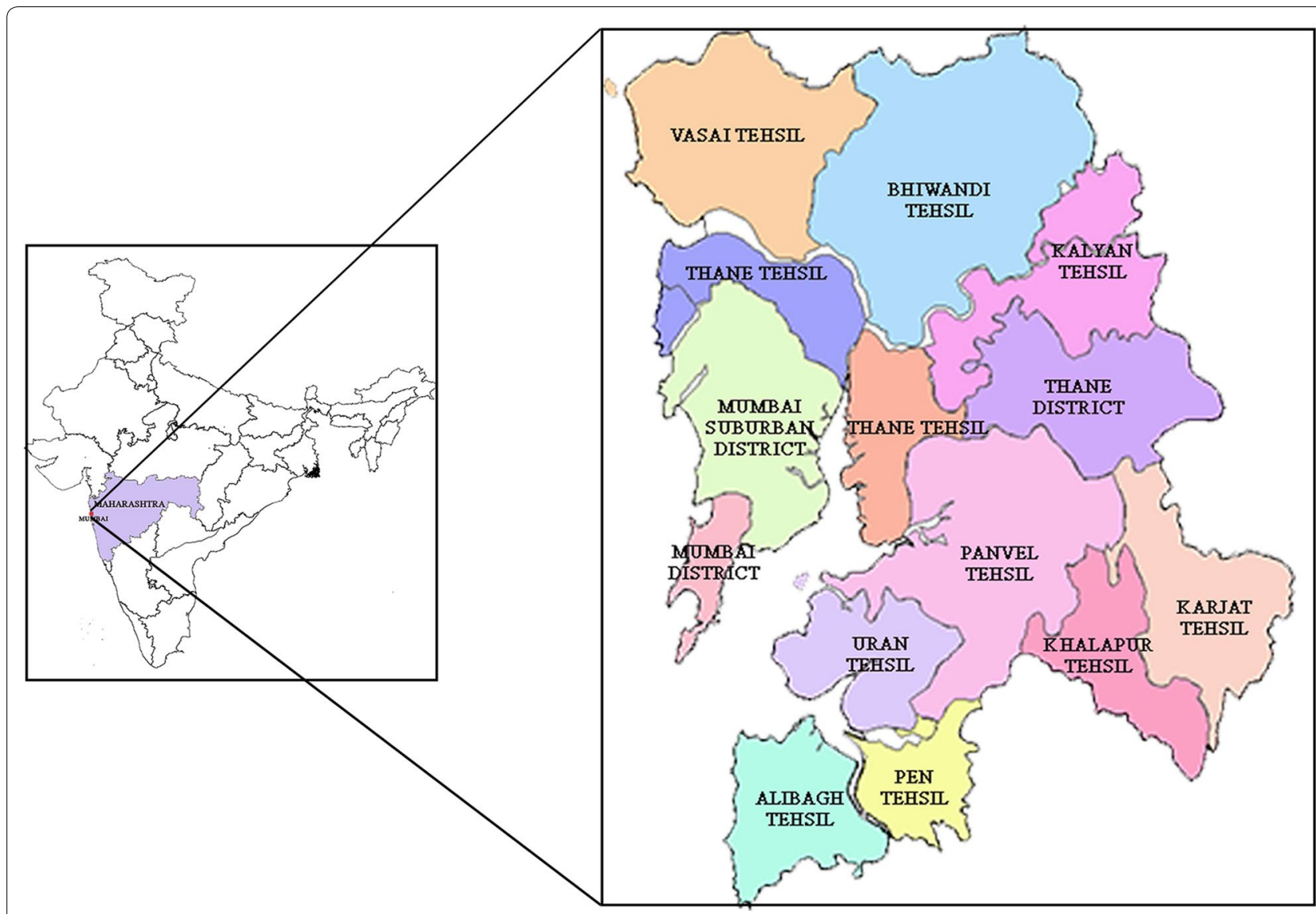

Fig. 1 Map of India showing the location of Maharashtra and Mumbai (left) and the districts of MMR (right)

2. Planning authorities were interviewed to understand their views on the climate change strategy in the region and to collect documents related to the regional plans.

3. Discussions were held with stakeholders.

4. A comprehensive study of the regional plans was conducted and the practical effects of each component of the regional plan in the region were ascertained.

5. Change Planning Index of the Regional Plan was calculated and the results are provided in the form of graphs to ease understanding at a single glance.

To understand the ideology of the MMR's planning authorities in the context of climate change, the Regional Plan 1996-2016 was studied. The study assumed that these planning documents are result of the region's cognition of climate change learning and reasoning, and therefore reflect the strength of the mitigation and adaptation strategies to be implemented.

\section{Mumbai Metropolitan Region (MMR)}

MMR is a metropolitan region with an area 4311.75 sq. $\mathrm{km}$ built around Mumbai city at the core and is one of the largest urban agglomerations in the world. The population of MMR is 22,804,355 (MMRDA 2017). It is located on the western coast of India in the state of Maharashtra (refer Fig. 1). MMR includes eight Municipal Corporations, nine Municipal Councils, and more than 1000 villages (DES 2016). The boundary of MMR has been modified several times in the past. The present boundaries of the region consist of districts subdivided into tehsils ${ }^{2}$ and villages. Following is a list of the current major units of MMR (MMRDA 1996a, 2017):

1. Mumbai City District

2. Mumbai Suburban District

3. Parts of Thane District

2 Tehsil: an administrative sub-division of districts as per Government of India. 
(a) Thane, Kalyan, Bhiwandi, and Ulhasnagar Tehsil

(b) Vasai Tehsil

\section{Part of Raigad District}

(a) Uran Tehsil

(b) Panvel, Karjat, Khalalpur, Pen, and Alibagh Tehsil

The region has a long coastline of $840 \mathrm{~km}$, which makes it highly prone to the events of floods and sea level rise. Kumar et al. (2008) deduced the development of construction zones in the floodplains and coastal areas as the reason. Floods, hail storms, heat waves, droughts, and wild-fires are the most common type of disasters related to climate (Recent Natural Disasters 2016). The pie charts in Fig. 2 depicts that Mumbai city with $18.48 \%$ share of the national population in 2011 has the highest share of such disasters. Flash floods and continued heavy rains are the most recurrent ones. As a coastal city, Mumbai is also prone to sea level rise, as heavy rains are a routine during monsoons. The Mumbai floods of July 2005 are an irrefutable example of insufficient planning standards. Unabated illegal construction in coastal areas and clogging of drains for various reasons were identified as the reasons for the catastrophe. The British daily newspaper, The Guardian (2014), predicts a similar flood occurrence in Mumbai before 2080, remarking that the city is still not ready to face these challenges. Based on these statistics, it is important to understand the needs of the city and work towards a better future.

\section{Urbanization and growth in MMR}

Population growth in MMR has been remarkable. Greater Mumbai which is the core city of MMR, has always been a hub of commerce and trade. This contributed towards the rapid urbanization of MMR. Table 1 shows the population of different Urban Agglomerations (UAs) in MMR from 1901 to 2011 (Census of India 2011) and Fig. 3 shows their location in MMR. Greater Mumbai (Mumbai city) has always been more populated than the other UAs (Fig. 4). It can be seen that until 2001, the population of greater Mumbai has been at a constant rise; however, after this, a downward slope is evident. In addition, the population of other cities demonstrates an upward slope from 1960s (Fig. 4).

Increasing urbanization in MMR has been studied with the help of the GIS-generated land use maps shown in Fig. 5. LANDSAT imageries downloaded from earth Explorer were employed for the years 1989 (December), 1998 (February), 2008 (October), and 2016 (December). In particular, the imagery with no external intervention was analyzed for each year to prevent error in the analysis. After preprocessing, maximum likelihood classification was performed to determine the land cover.

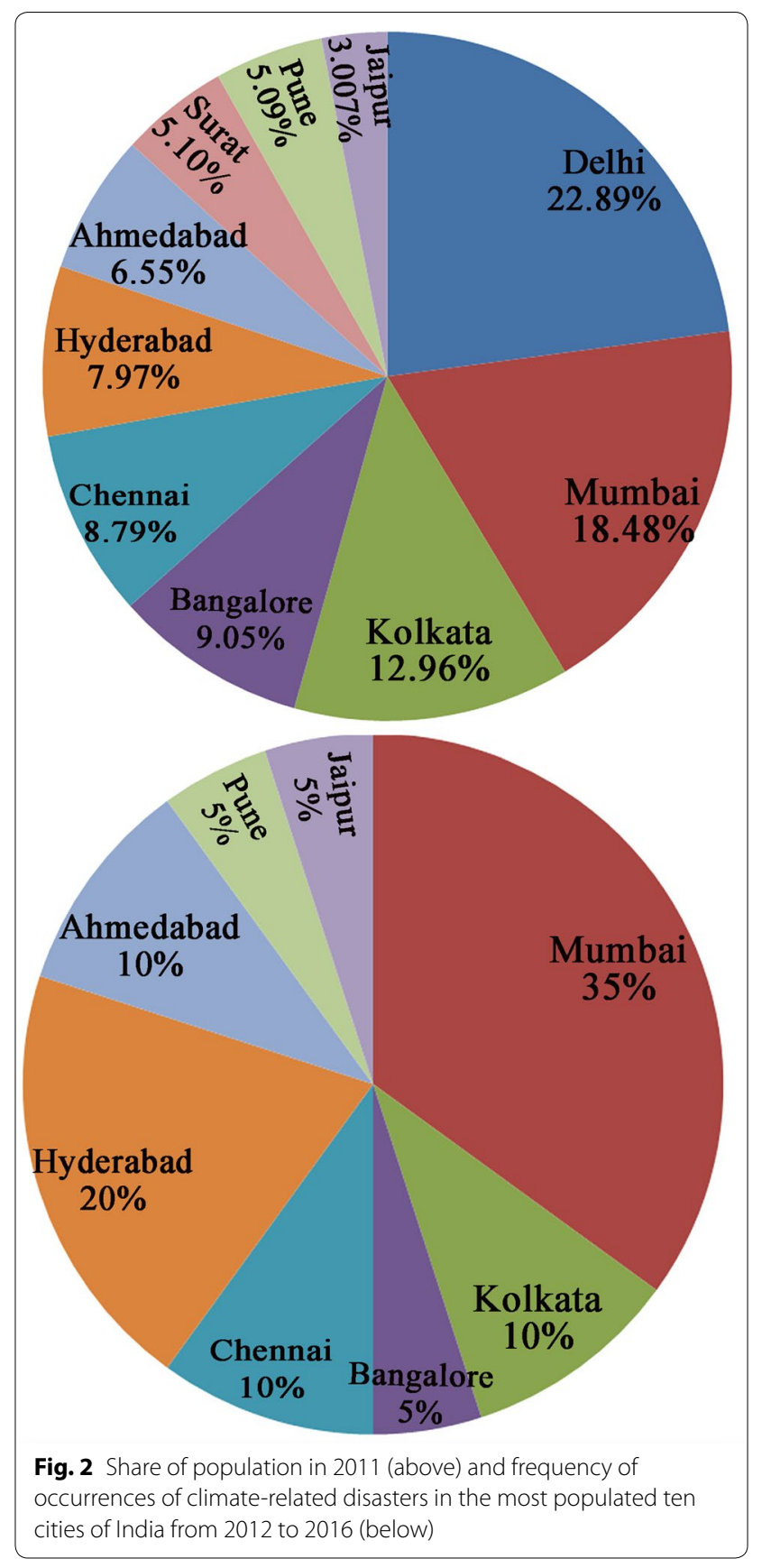

It can be observed that in the past, Greater Mumbai was the center of urban land cover. However, as it started showing signs of saturation, the urban land cover began spreading to the surrounding region, mainly concentrated in Thane and Kalyan, also extending to the New Mumbai and Panvel. Figure 6 graphically shows the increasing proportion of urban cover in MMR. The trend line in the figure provides evidence of the exponential increase in the share of urban over other land uses. 


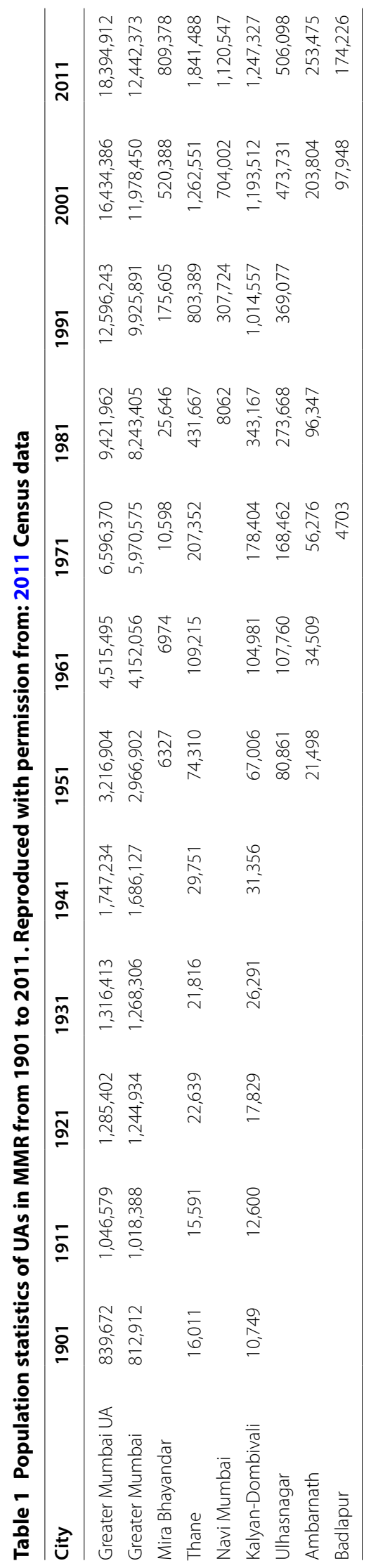




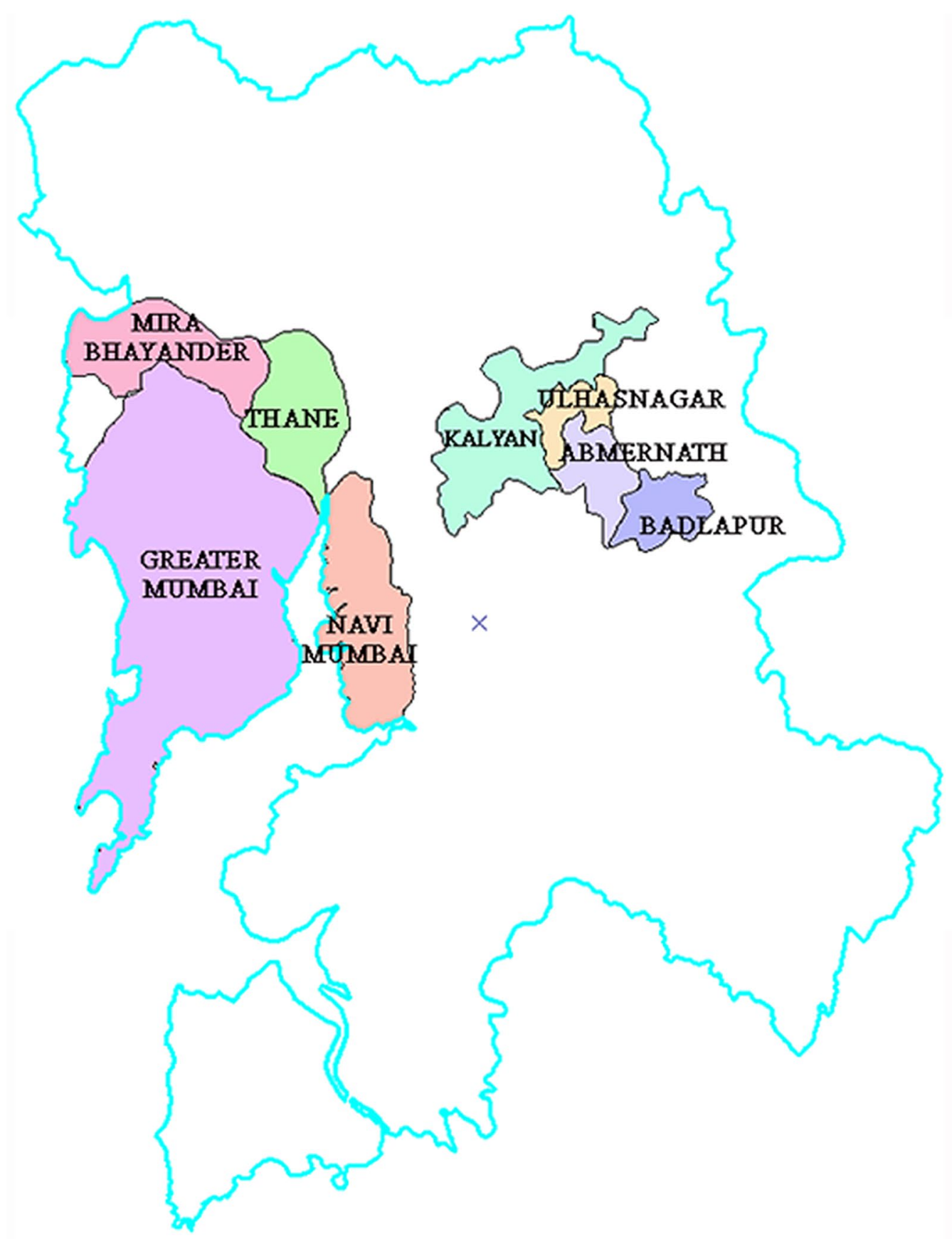

Fig. 3 Most populated UAs in MMR

\section{Urbanization challenges}

Currently, MMR is facing multitude of urbanization disadvantages like urban poverty, growing informal sector, electricity shortage, and poor sanitation. Seemingly neverending land requirements are being addressed through the conversion of green zones, flood plains, saltpans, watersheds, and coastal areas into construction zones, which has become common practice. The increasing energy requirement for infrastructure (transport, water supply, electricity, sanitation) is mainly fulfilled by burning fossil fuels. The overall average consumption of fossil fuels worldwide is decreasing; however, that for India is continuously increasing (The World bank Data 2017). Quarrying is a major means to obtain the raw material needed for construction (MMRDA 1996b, 2017). Furthermore, the solid waste management system is not regularly updated 


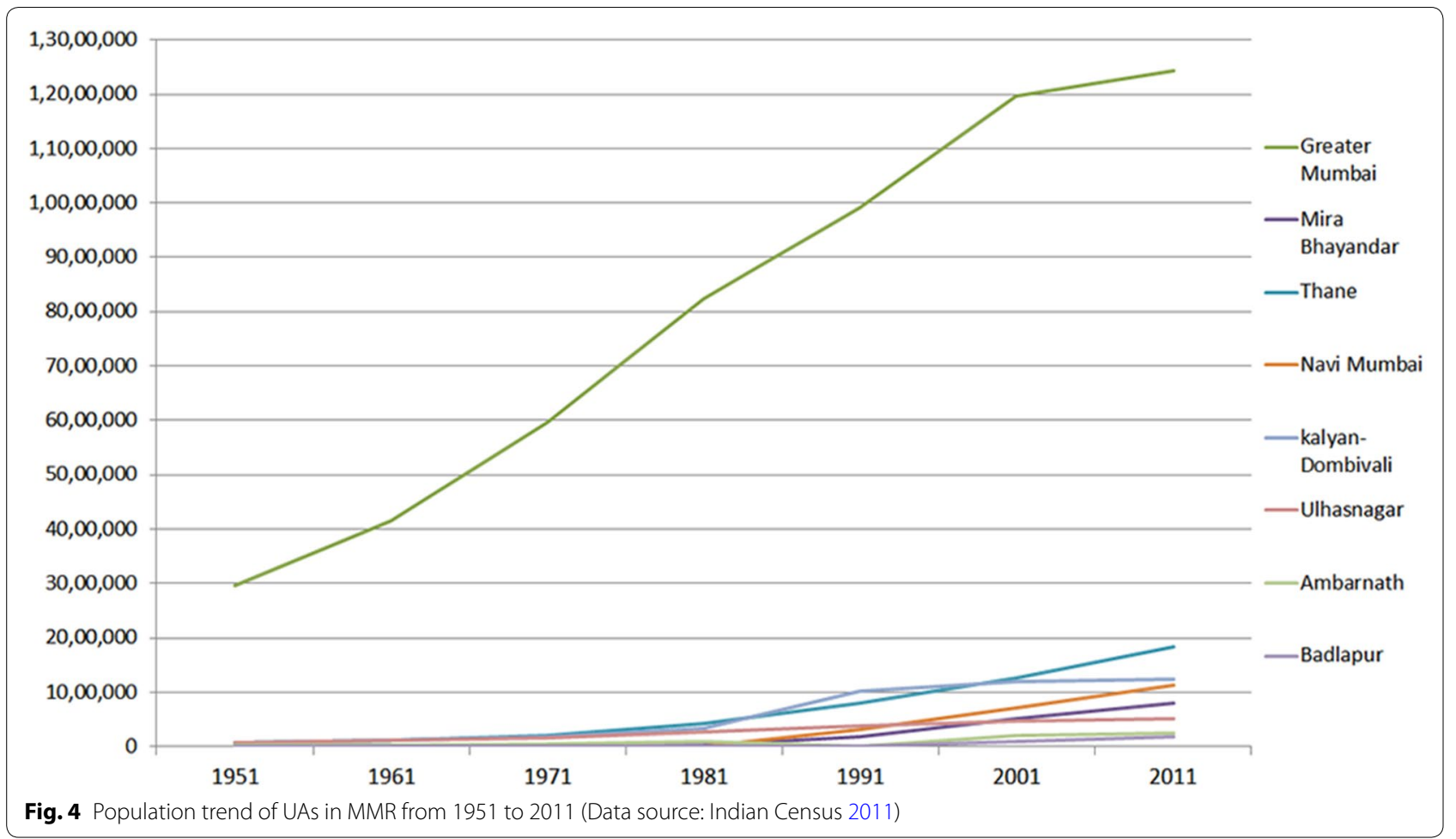

to cater to these increased demands (Kumar et al. 2009) and the insufficient drainage system adds to the problems of residents of these areas (Patil and Shekdar 2001). The already deficient storm water drains are further blocked by the solid waste produced by the increasing population. The combined effect is a damaged environmental system, the consequence of which is seen in the form of floods and other extreme unexpected weather systems.

\section{Regional planning in MMR}

By the mid-nineteenth century, the explosion of the population and industries followed by land scarcity crowded Greater Mumbai and ended up in making the system unmanageable and causing a bursting rise in land prices. This resulted in rapid growth of the city's informal sector. In 1958, solving the suffering in Greater Mumbai began to be considered. That year, the idea of planning a twin town towards the east (across the harbor) of the city emerged. Instigated in 1964, this idea finally materialized in 1970, when the City and Industrial Development Corporation (CIDCO) of Maharashtra was established for the task (Jain 2011). The new town was named New Mumbai, and was planned to accommodate a population of about 21 lacs. This city was to function as the counter magnet to Greater Mumbai. Further on, the focus was also laid on planning of various other smaller business centers on the transport link connecting the peninsular island with the eastern mainland, the main areas being Thane, Ulhasnagar,
Bhiwandi, Khopoli, Kalyan, and Dombiwali. The aim was to draw urbanization to the eastern mainland to dissipate the pressure on Greater Mumbai (CIDCO 1973).

For the smooth planning of the entire region as a single unit, the Mumbai Metropolitan Region Development Authority (MMRDA) was established on March 1, 1975. The authority is now responsible for planning, coordinating, and supervising the development of the region and executing related plans and projects (MMRDA Act 1974). It works for the development of growth centers aimed at improving sectors such as transport, water supply, housing, and the environment in MMR. For this purpose, MMRDA publishes Regional Plans (RP) for MMR. These plans span over a period of 20 years, after which they are revised and newly sanctioned for the next 20 years. The box below is the timeline of the implementation of the 3 RPs of MMR.

\begin{tabular}{llll}
\hline & & $\begin{array}{l}\text { Supposed duration } \\
\text { of implementation }\end{array}$ & $\begin{array}{l}\text { Sanction } \\
\text { year }\end{array}$ \\
\hline 1 & First Regional Plan of MMR & $1970-1991$ & 1973 \\
2 & Second Regional Plan of MMR & $1996-2011$ & 1992 \\
3 & Third Regional Plan of MMR & $2016-2036$ & - \\
\hline
\end{tabular}

To date, two plans for the MMR have already been published, namely, the Regional Plan 1970-1991 and Regional Plan 1996-2011. For the context of this study it is noteworthy that the third RP, which was to be implemented from the year 2016 to 2036, is currently 

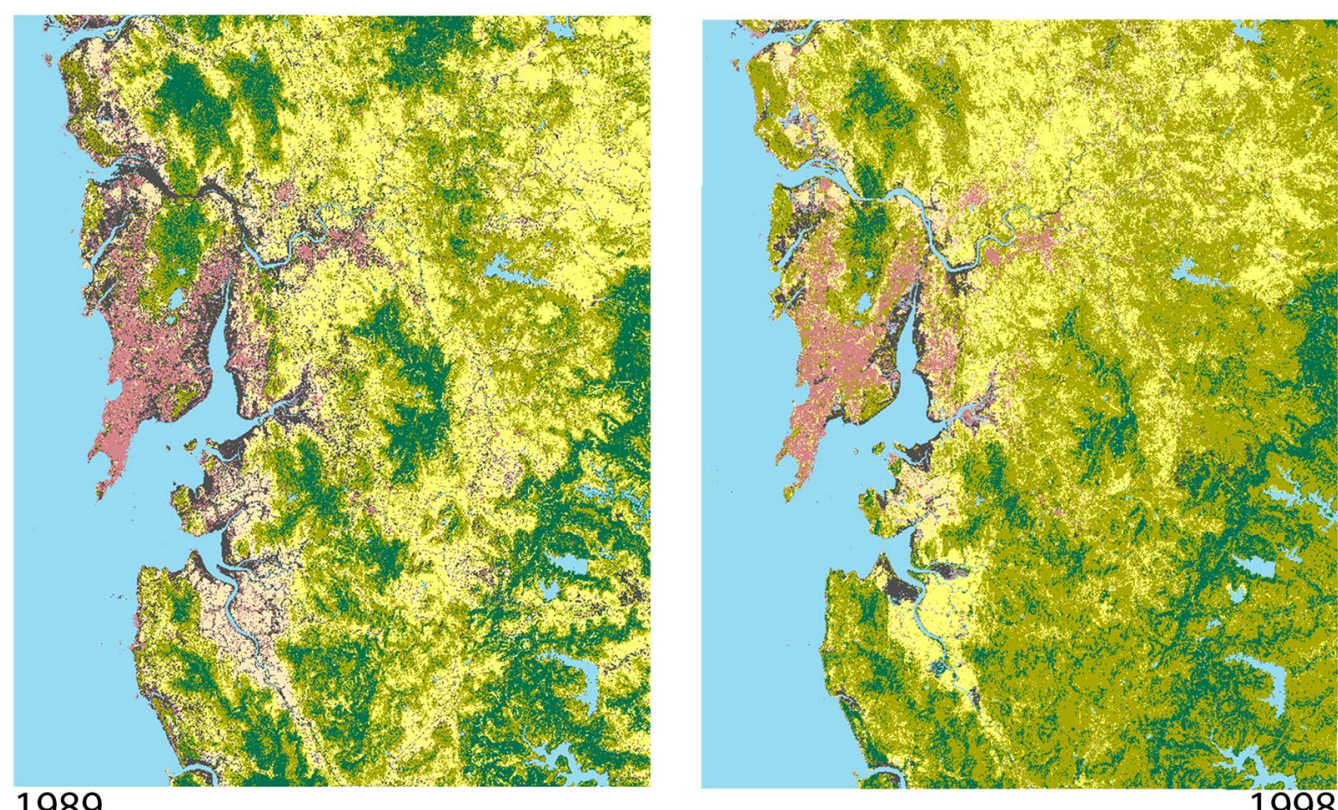

1989

1998
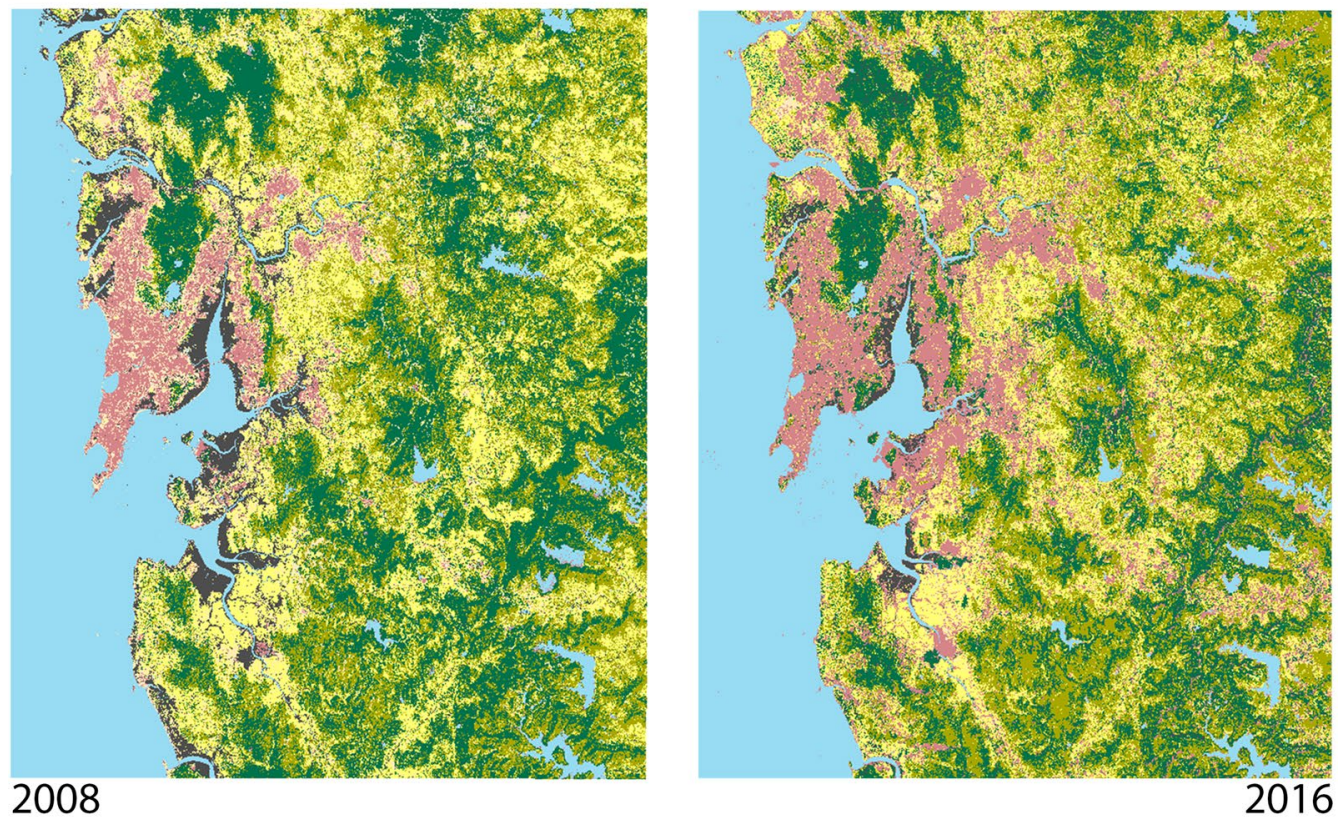

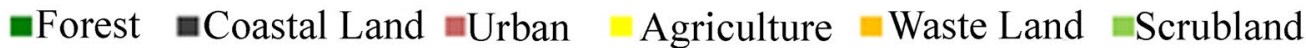

Fig. 5 Land cover maps of MMR for the years 1989, 1998, 2008 and 2016

undergoing the hearing process in order to take into account the public objections and suggestions. Hence, RP 1996-2011 is selected for the study. There are two important reasons for this selection. Firstly, the RP 1996-2011 has the longest duration of implementation in MMR. It was supposed to be ending in 2011, but the implementation period is still in continuation. Secondly, the third RP has yet not been published. Hence, the second RP
(1996-2011) continues to be in force in MMR until the third RP is published and sanctioned.

\section{Regional Plan 1996-2011}

Members of MMRDA, a huge executive committee and an extendedly large group of planners were involved in the formulation of this RP. Support from other institutes, 


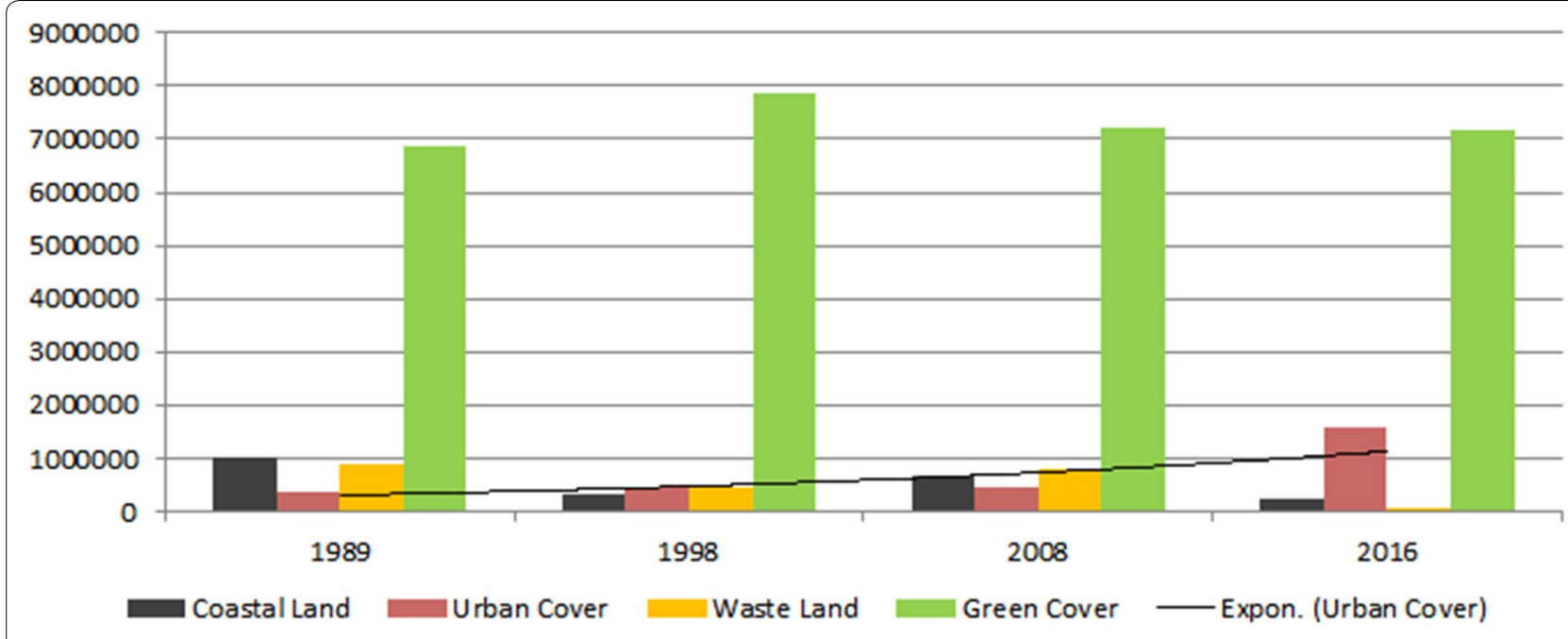

Fig. 6 Land cover share in MMR in the years 1989, 1998, 2008 and 2016

NGOs and academic institutions was taken. RP 19962011 which was sanctioned in 1992 consists of three parts further divided into 17 chapters. Part I talks about the general characteristics and regional strategy of RP. Part II mainly discusses the proposed policies regarding industrial growth, office location, shelter needs and strategies, urban land policy, water resources, transportation and environment. Part III demonstrate the legal binding of these policies and discusses about the controls and regulations under which these laws are to be abided.
For the scope of this paper, the each chapter present in RP which talks about policies and their implementation guidelines is termed as a component of RP, and the sub-sections of each chapter are referred to as the subcomponents. Table 2 lists the different components of the regional plans, its objective in brief, number of sub-components and number of pages in the chapter.

Discussed by Young (2016) in the study in Santos, Mexico, the present study also assumes that these planning documents are result of the region's cognition of planning

Table 2 Regional Plan 1996-2011: components, objectives, number of sub-components, and number of pages

\begin{tabular}{|c|c|c|c|}
\hline Components of Regional Plan 1996-2011 & Objective & $\begin{array}{l}\text { Number } \\
\text { of sub- } \\
\text { components }\end{array}$ & $\begin{array}{l}\text { Number } \\
\text { of pages }\end{array}$ \\
\hline Regional Development Strategy & $\begin{array}{l}\text { Establishing links with national plans, allocating power and resources, plan- } \\
\text { ning investments and budgets }\end{array}$ & 5 & 4 \\
\hline Industrial Growth Policy & $\begin{array}{l}\text { Regulating the location of industrial development, relocating them to } \\
\text { prospective areas identified for future development }\end{array}$ & 3 & 38 \\
\hline Office Location Policy & $\begin{array}{l}\text { Regulating the location of tertiary activities, i.e., sectors other than agricul- } \\
\text { ture, manufacturing, trade, and commerce }\end{array}$ & 3 & 25 \\
\hline Shelter Needs and Strategies & $\begin{array}{l}\text { Strategy relating to shelter increment, slum improvement, and maintaining } \\
\text { existing housing stock }\end{array}$ & 4 & 52 \\
\hline Urban Land Policy & $\begin{array}{l}\text { Ensuring efficient regulation of land ownership, prices, usage, and flexibility } \\
\text { in a growing city }\end{array}$ & 3 & 27 \\
\hline Water Resource Development & $\begin{array}{l}\text { Regulation of water source development, conveyance, treatment, and } \\
\text { distribution }\end{array}$ & 5 & 25 \\
\hline Transportation & $\begin{array}{l}\text { Catering to the transportation needs of a growing population, maintaining } \\
\text { the present infrastructure, traffic management strategies }\end{array}$ & 4 & 31 \\
\hline Environmental Management & $\begin{array}{l}\text { Maintaining ecological balance, preserving places of environmental impor- } \\
\text { tance, speculating on the "expanse of development" }\end{array}$ & 13 & 32 \\
\hline Revised Land Use Plan & $\begin{array}{l}\text { Dividing zones and allocating land use according to projection and distri- } \\
\text { bution of population and employment }\end{array}$ & 12 & 31 \\
\hline Development Control & $\begin{array}{l}\text { Controlling specific types of development that may affect overall develop- } \\
\text { ment of the region by providing a legal framework }\end{array}$ & 4 & 16 \\
\hline
\end{tabular}


for the present and future taking into account all the aspects; strengths, weaknesses; needs and requirements of MMR where climate change learning and reasoning plays an important part, and therefore this RP reflects the strength of the mitigation and adaptation strategies to be implemented.

\section{Evaluation of Regional Plans}

The monitoring and evaluation of planning strategies has been a common research subject in the western countries from last few decades but in the Asian context, it is a relatively new field. Conroy and Berke (2004) used content analysis for evaluating community plans in US. Baynham and Stevens (2013), and Stevens (2013) used the content analysis as the basic technique, to evaluate the quality of the official Community Plans in British Columbia by analyzing specific factors designed in the previous studies. Raparthi (2014) used the technique for evaluating master plans of Indian cities. Norton (2008) discussed the advantages and disadvantages of using content analysis for plan evaluation by evaluating plans of Central Michigan and concluded with explain the proper use of the technique for the same. Tang et al. $(2011,2013)$ use this method in the coastal states in US for evaluating the plans for extreme weather vents. For different contexts, different modifications have been done to the basic technique. Finally, the technique used by Raparthi (2014) in the Indian cities forms the basis of the technique developed in the present paper. However, it has been modified to address existing gaps.

\section{Climate Change Planning Index (CCPI)}

Raparthi (2014) analyzed 64 master plans for climate change mitigation issues by employing the content analysis method. The plans were evaluated against a distinct set of protocols, which were the same for all the 64 master plans. The integral policies/strategies/plans of the master plans were not evaluated per se which neglects the context of the master plan. Instead, irrespective of the contextual diversities, all plans were scored against a pre-decided set of indicators named the "mitigation evaluation protocol'. The indicators were as follows: land use, urban design, physical planning, building specifications, transportation, environment, incentive, education and attainment tools, and physical infrastructure. While it is understood that the planning documents may correspond differently to various aspects of climate change evaluation, this method was highly subjective, resulting in a high probability of error. Therefore, in the present study, the policies of the regional plan (enumerated as separate chapters in the planning documents) are used as components and sub-components, and the individual scores are imparted for each sub-component through content analysis method. Content analysis has been actively used in various researches. Norton (2008) elaborated the usability of content analysis in evaluating master plans.

Summarizing up the scores of sub-components, the overall score of the component as a whole is determined. Next to this, the weightage of each of the component was determined by means of survey questionnaires. The respondents were planners from MMRDA and other planning authorities in MMR who are involved in the making and implementation of different plans for MMR. The other respondents were planners who are the members of NGO based in Mumbai; working in the field of climate change and researchers from planning institutes. Personal interviews were conducted on the field trip as well as online surveys were conveyed. To ensure an unbias result, equal number of respondents were selected among the government and the non-government employees for the interviews. From the final weightage scores (refer Table 3), it was found that 'transportation' component of RP scored the highest weightage while

Table 3 Weightage of the components and calculated Climate Mitigation and Adaptation Score

\begin{tabular}{lllll}
\hline Components of Regional Plan 1996-2011 & $\begin{array}{l}\text { Number of sub- } \\
\text { components }\end{array}$ & Weightage & $\begin{array}{l}\text { Climate Change } \\
\text { Mitigation Score }\end{array}$ & $\begin{array}{l}\text { Climate Change } \\
\text { Adaptation } \\
\text { Score }\end{array}$ \\
\hline Regional Development Strategy & 5 & 3.38 & 1 & 1 \\
Industrial Growth Policy & 3 & 3.31 & 1.7 & 1.7 \\
Office Location Policy & 3 & 3.19 & 5 & 1.7 \\
Shelter Needs and Strategies & 4 & 2.75 & 0 & 0 \\
Urban Land Policy & 3 & 2.88 & 0 & 0 \\
Water Resource Development & 5 & 3.50 & 3.5 & 2 \\
Transportation & 4 & 3.81 & 3.37 & 1.25 \\
Environmental Management & 13 & 3.56 & 2.5 & 5.77 \\
Revised Land Use Plan & 12 & 3.50 & 2.5 & 5 \\
Development Control & 4 & 3.63 & 2.65 & 1 \\
CCPI of RP 1996-2016 & & & & 1.94 \\
\hline
\end{tabular}


'shelter needs and strategies' scored the lowest suggesting that in MMR, transportation is the most important factor for attempting to fight the climate issues. Following this, the CCPI for the regional plan is estimated using a set of rules. The aim of CCPI is to calculate the strength (or weakness) of each component of RP. It is important to note here that in this process, no new set of parameters is used; rather, the inherent policies of the regional plan are analyzed to calculate CCPI which marks the advantage of this method and makes the study unique. Steps were designed in a way to keep it simple yet useful, so that the technique is applicable to planning document of any kind. For mitigation index, the sub-components were evaluated in terms of 'greenhouse gas (GHG) reduction potential'; while for Adaptation Index, sub-components were evaluated to 'check their ability to reduce vulnerability and resilience building capacity'. The regional plans were thoroughly studied and deductions were made based on author's understanding of climate change adaptation and mitigation; which is the foundation of the analysis. This method is fully based on the analyst's perspective, which in a way can be noted as a disadvantage of the proposed method. However, the authors' have tried to overcome this drawback by using the weightage scores obtained through surveys and having a critical discussion over CCPI with the key persons in MMR. During the development process of this method, various field surveys were conducted and a series of discussions were held directly with the stake holders. The whole idea-procedure, methodology as well as results, has been through a strict critical analysis during this process after which, it has evolved into an explicit tool.

Scores ranging from 0 to 2 were assigned to each subcomponent proposed in the regional plans as follows:

- A score of 0 was assigned to a sub-component if there is no consideration of climate change.

- A score of 1 was assigned to a sub-component if it addresses environment or climate change as an objective directly/indirectly.

- A score of 2 was assigned when the sub-component has climate change or environment protection as a mandatory objective.

This was performed for each component of the Regional Plan for mitigation and adaptation separately. Using these scores, a Climate Change Mitigation Index and Climate Change Adaptation Index was formulated, which in its combined form is termed as Climate Change Planning Index-CCPI. The steps taken to calculate the Climate Change Mitigation Index are explained below.

\section{Steps to calculate the Climate Change Mitigation Index}

Step 1: Assign scores to each plan/strategy and its sub-parts (components) on a scale of $0-2$.

Step 2: Calculate fractional score for each component: divide the assigned score by the maximum possible score of all components together.

Step 3: Add all fractional scores for each policy/ strategy.

Step 4: Standardize the fractional score by multiplying it by 10 . This is the index score for each strategy proposed in the plan.

Step 5: Calculate the Climate Change Policy Score of the Regional Plan by calculating the average of all the above.

These steps were repeated for the Climate Change Adaptation Index. Following these steps for all the components, CCPI for the Regional Plan 1996-2011 was derived.

\section{Results and discussion}

Table 3 provides the results of the CCPI calculated for RP 1996-2016 of MMR. These indices indicate the level of consideration of climate change mitigation or adaptation in each component in the regional plans, termed the Climate Change Score.

It was found that out of 10, the Climate Change Mitigation Index for this regional plan was 2.65, while the Climate Change Adaptation Index was 1.94, which is low considering the climate change issues in the region. The scores of the components are low, which resulted in the low CCPI of the regional plan. In Table 3, none of the components scored $100 \%$. The highest score was 7.5 for the mitigation of transportation, while the second highest was much lower (5.77) for adaptation for environmental management. Only a few components have scores greater than or equal to 5 , while more than two-thirds scored below 5 . Moreover, two components scored 0 symbolizing absolutely nil connection with climate priorities.

To ease understanding and ensure that the results are visually legible, the ideal score and calculated scores for mitigation and adaptation were mapped as sunburst charts, the explanation of which is given in Fig. 7. Finally, Fig. 8, shows CCPI in case of an ideal scenario, while Figs. 9 and 10 show mitigation and adaptation potential of RP 1996-2011in MMR respectively.

In each figure, one wedge represents one component of the regional plan. Individually, each wedge consists of the length of the arc and number of concentric circles it covers (refer Fig. 7). The length of the arc of each wedge represents the number of sub-components it 


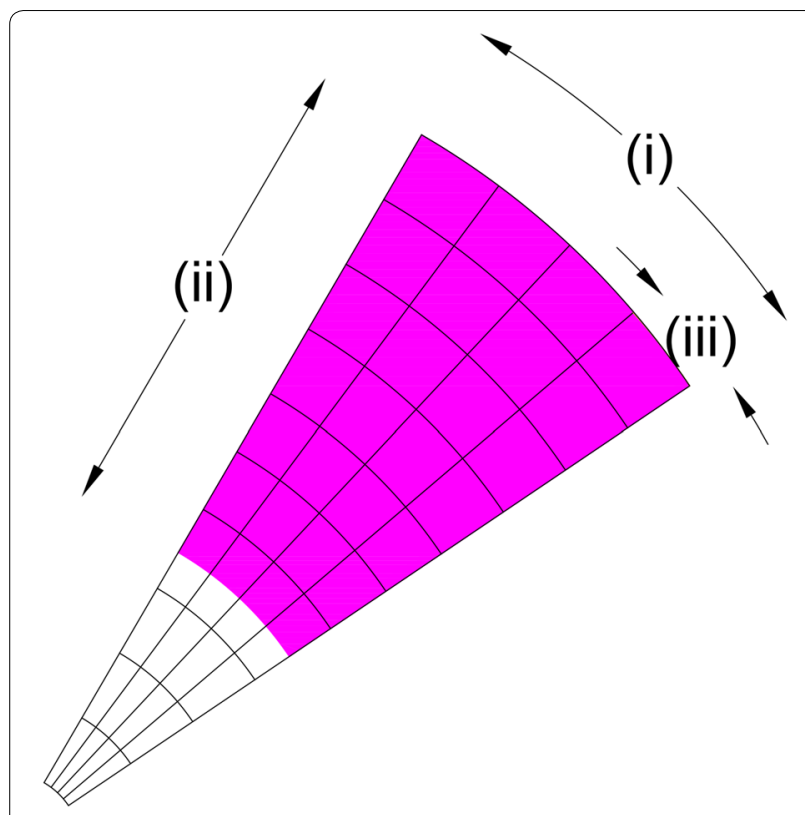

Fig. 7 Explanation of CCPI graphs comprises (i) The number of concentric circles it covers represent the resultant score of each component. (ii) The longer the arc, the higher the value of subcomponents, which implies increased possibilities of advancement in the component. The higher the number of concentric circles covered, the better the current potential to climate change protocol. In addition to that, the arc length (iii) of each sub-component represents the weightage it has scored through the interview surveys. As a whole, the figures represent the potential of the RP in terms of the climate change protocol. The larger the wedge, the stronger the mandate for climate change and vice versa. For example, Fig. 8 is a case of an ideal scenario wherein each sub-component has a score of 2 and each component has a score of 10 (maximum score); thereby, the overall index is calculated as 10 . Analyzing the RP 1996-2011, the results were far from ideal. The results presented in Table 3 are mapped in Figs. 9 and 10. How well (or unwell) the RP 1996-2011 considers climate as mandate was deduced. The following section clarifies the implications of these estimated

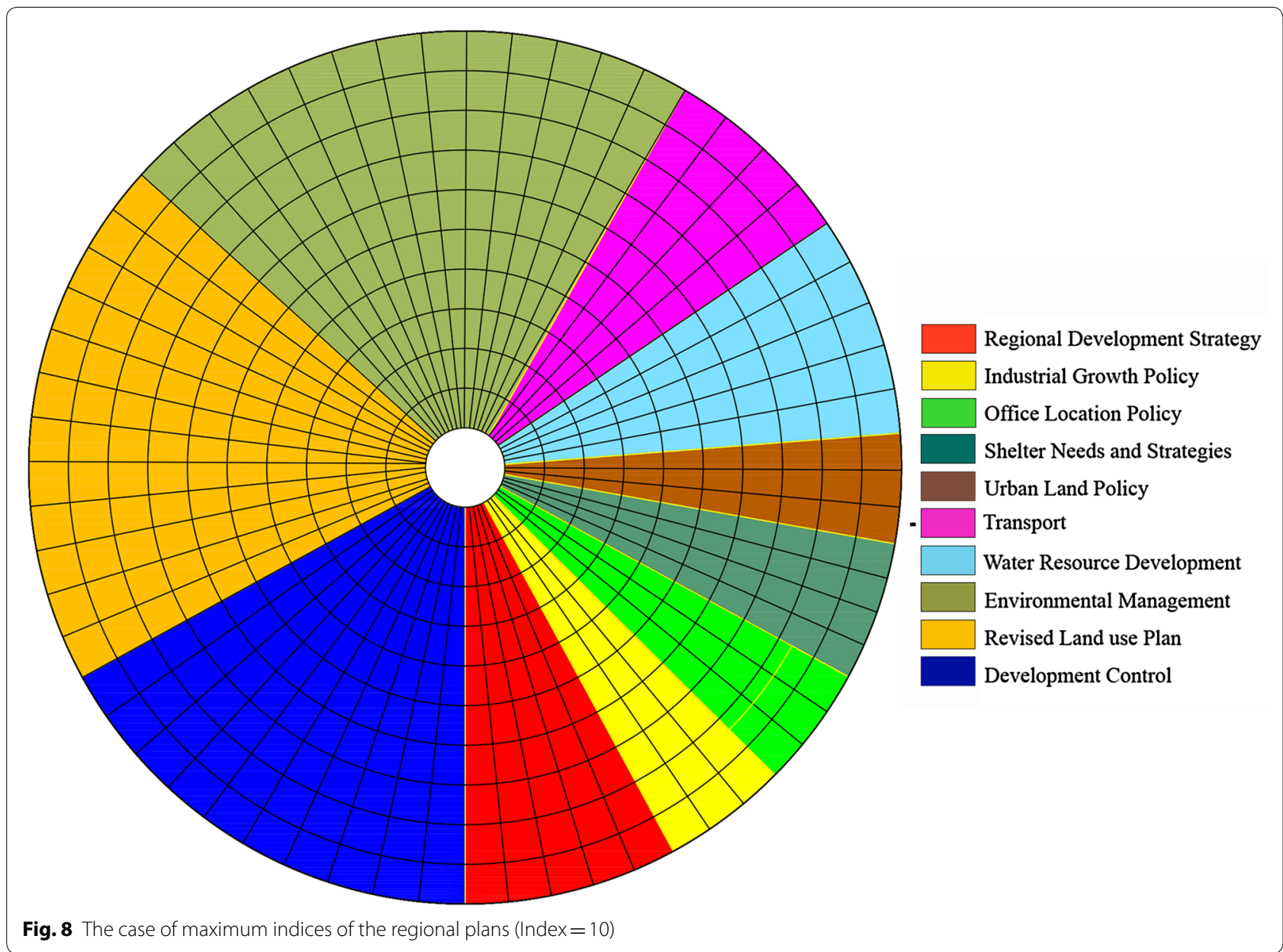




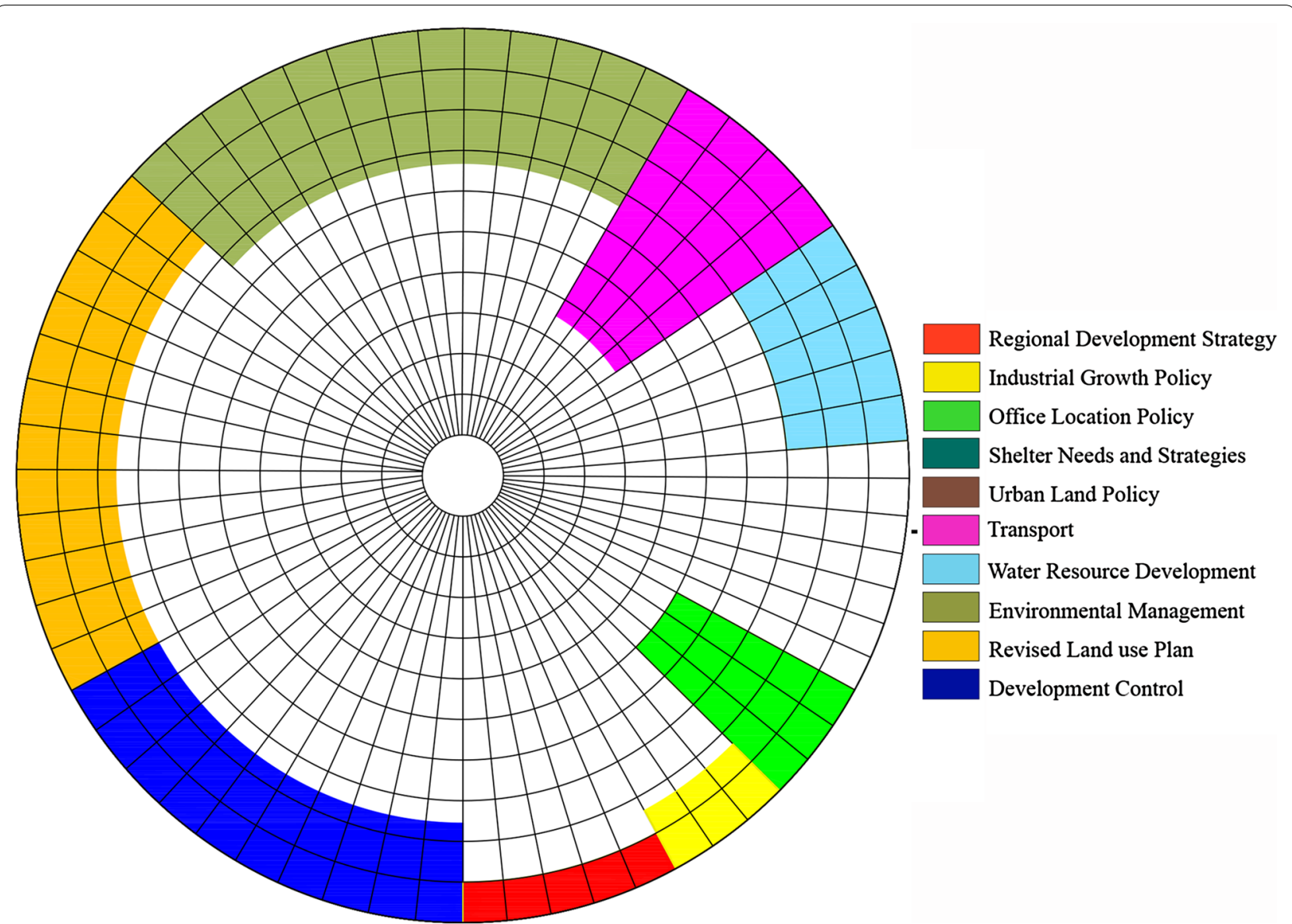

Fig. 9 Climate Change Mitigation Index (average score $=2.65$ )

indexes and scores for each component, and explains their meaning in the regional planning document.

The low value obtained in the analysis indicates a weak relation between the regional plan and the climate change mitigation and adaptation protocols. The Regional Development Policy, with a score of 1 for both mitigation and adaptation, demonstrates a weak link between the regional plan and the National Climate Action Plans. The total number of sub-components is 5 , and the goal of the strategy is to mobilize resources in a way beneficial to the public. However, the results suggest that this goal is not directed towards achieving a resilient environment. Climate change as a threat to society is not considered, and resources are not distributed considering this aspect.

The score of the Industrial Growth Policy (number of sub-components $=3$ ) is also low. The score 1.7 portrays a weak industry location scheme, suggesting that the location of new industries does not really consider environmental aspects. The main objective of this strategy was to decentralize Mumbai city and distribute future growth to the surrounding areas. But, during this, climate change and environmental issues are either ignored or not prioritized. However, for the same reason, the mitigation score for the Office Location Policy is high (mitigation score $=5$ ). This strategy pertains to regulating tertiary activities in the region, which has the highest share in the type of occupation. With three sub-components, the aim is to reduce the floating population, which is appropriate considering the mandate of decentralization. However, the adaptation score is 1.7 , suggesting that for the already existing tertiary activities in the region, only a few regulations aim to reduce vulnerability or increase resilience to the risk of climate change.

The next two objectives of the regional plan are Shelter Needs and Strategy and Urban Land Policy with four and three sub-components respectively. These two policies are the weakest in considering the climate change protocol. The reason can be attributed to the large volume of people moving into the region, who setthe in unregistered, informal shelters. As early as 1977, MMRDA realized the enormous demand of housing 


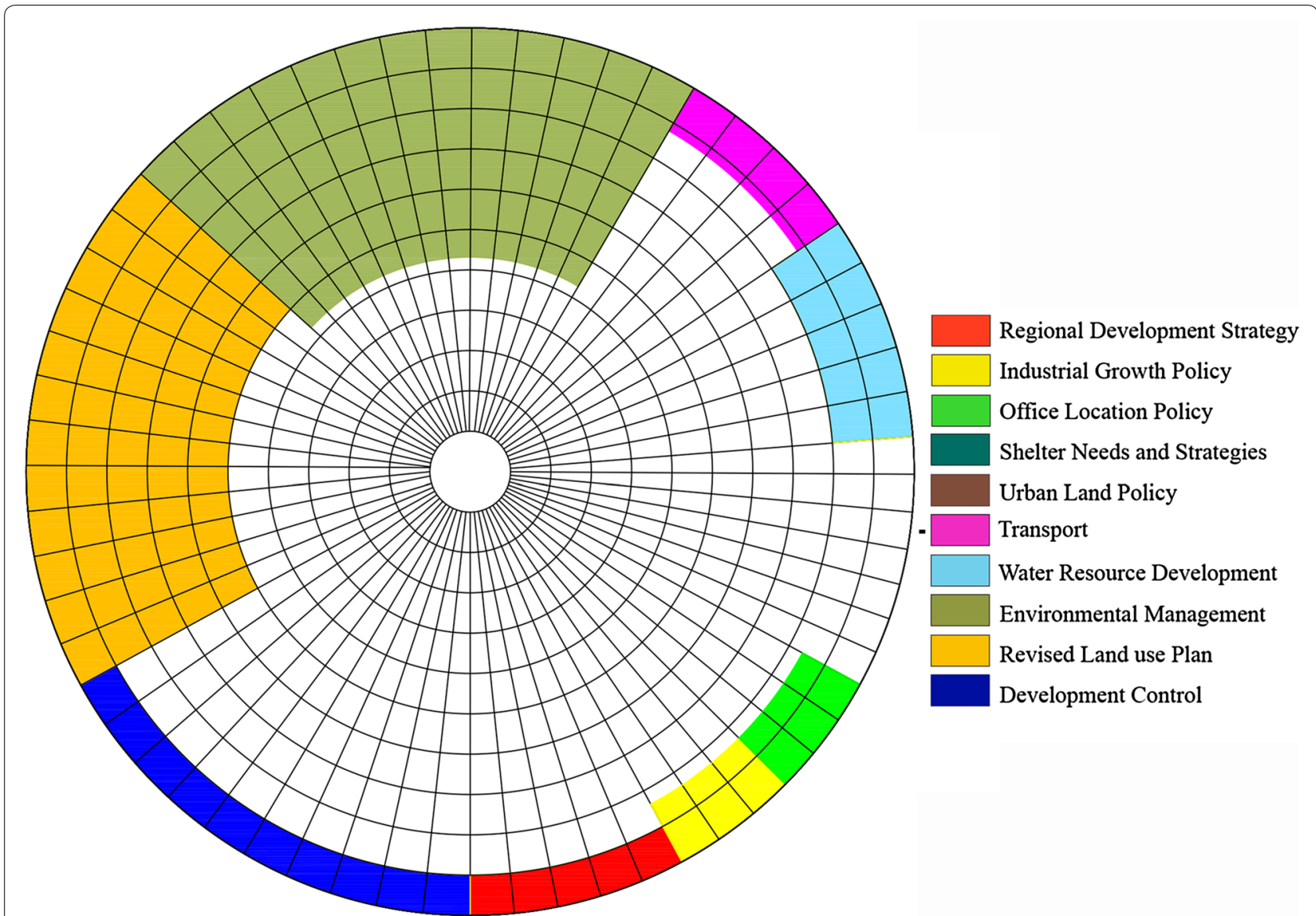

Fig. 10 Climate Change Adaptation Index (average score = 1.94)

in Mumbai. It was found that in total, 60,000 houses per annum were required, but the supply per annum was only 20,000 (Dutt et al. 1994). Now in the twentieth century, the scenario is the same. However, a new angle has emerged. Although, Times of India (2012, 2017) reported a large percentage of vacant houses in the MMR; the housing demand has still not decreased. This is because of imbalanced ownership and severe lack of homogeneity in the city-characteristic of the region for some time (DNA 2009). The next objective of the regional plan, Water Resource Development with five sub-components, is responsible for regulating the sources of water and supply. The Climate Change Score estimated for mitigation is 3 , while that for adaptation is 2 for this objective. In MMR, water recycling is aimed for, but the immense population and informal settlements make it difficult to maintain, which is the reason for the low scores.

However, transportation in MMR considers environmental issues. Trains and buses are used for $75 \%$ of motorized trips, and only $2.6 \%$ of households own cars in MMR (Cropper and Bhattacharya 2012). As a result, emissions due to road transportation in Mumbai are much lower than in other metropolitan cities in India (Das and Parikh 2004; Ramachandra and Shwetmala 2009; Ramachandra et al. 2014). This is reflected in the mitigation score of 7.5. However, the adaptation score is low at 1.25 , which indicates that improvements can be made for this aspect in the transportation sector. Furthermore, the transportation component has only four sub-components.

The environmental issues emerging in MMR were previously identified and acknowledged. Many policies focus on protecting the environment. This is the probable reason for the comparatively high adaptation score estimated for the environmental management component of the regional plan (adaptation score $=5.77$ ). However, there are also constituents in this component that need improvement. Certain zones were designated as no construction zones, although there are gap present in the regional plan where these rules can be modified. For example, severe restrictions on developments in the Coastal Regulation Zones to be implemented are mentioned in the regional plan. However, certain conventions 
prevail that can potentially alter the regulations. In addition, even though no official construction may occur in the no development zones earmarked in the development plans, informal and unregistered construction is always present. The next component of the regional plan-Environmental Management comprises of 13 sub-components, the highest number in the regional plan. Despite this, the low score for mitigation (3.37) reflects the space for improvement.

The aim of the Revised Land Use Plan, which has 12 sub-components, is to divide zones and allocate land use according to the population and employment projection. The mitigation score is 2.5 , which is low, and the adaptation score is 5 , which is average. In MMR, as discussed earlier, the large population has resulted in planning several business districts in the region. This has amended the flow of population for employment, but also increased urban land cover. Therefore, while this strategy has helped, considering climate change issues, it has brought about more damage than benefits. However, these damages are not due to the relocation policy, but to the increasing population. Because of the unpredictable increase in population, the present strategy was not fully able to handle the issue, which is the reason for the low scores.

The last component of the regional plan is 'Development Control' which has four sub-components. It aims to provide a legal framework to control development in different parts of the region to benefit overall development. It defines laws and regulations to ensure Government's control of development in MMR. The scores for mitigation and adaptation are 2.5 and 1 respectively. As explained for the environmental management component, the laws are not able to provide rigorous protection of the natural environment; several shortcomings are evident. Thus, even though MMR has laws pertaining to environmental issues, these are not strict enough. Moreover, the development plans of cities sometimes conflict with the laws, and no strict provisions ensure an overlap in the development and regional plans.

\section{Conclusion}

MMR is facing a series of urbanization issues, which are responsible for the increased threat of climate-related disasters. Hitherto, the regional plans of MMR are unable to incorporate strict climate change mitigation strategies. The reason can be attributed to increasing and uncontrolled urbanization. Considering this and limited resource availability, the status of the regional plans of MMR as not being able to prioritize climate change can be understood. In a phase where the city is failing to provide basic structure to its residents and is vulnerable to climate change risks, prioritizing climate change is a difficult decision. At best, the plans of such regions are expected to be flexible enough to ensure that development and environmental viability occur in parallel in a coordinated way. Planning authorities have to intricately carve their own way towards a safe present and sustainable future. This cannot be generalized, as each country, region, or city has its own needs, resources, strengths, and limitations.

Waldner (2004) analysed planning products and plan evaluation methods and found that monitoring and evaluation of plans is not well materialised into practicality. Lack of economic benefits, initial cost and input, political/legal requirements, cultural norms etc. have been identified as the reasons. In response to this, the present study suggests a simplified and comprehensive set of rules for plan evaluation. The CCPI tool designed in this paper presents new advancement for implementing climate change protocols in planning. By analyzing the present planning policies of a region, the analysis will have more impact and exert direct pressure on planning authorities in the region. It provides an immediate understanding of the status of climate change protocols in the current plans as it is already established that the mitigation and adaptation potential of the policies is directly related to this approach. Moreover, this method enables finding the weakest component or sub-component to be targeted to achieve equilibrium in planning. This provides a clear direction to the planners, policymakers, and key persons involved in planning/policy making. Furthermore, for the layperson, the results can be a tool to showcase the impact of current planning on the climate change scenario in the region. It is important to note that the study is not a criticism to the current plans of MMR, instead it can be used for enhancement and enrichment of the planning documents as these documents are expected to shape the future of the region.

\section{Plans in future}

The methodology developed in this study will be used for further analysis of the Regional Plans 1973-1993 and 2016-2036. After absolute analysis all three plans, a complete picture of climate change protocols in MMR's regional plans will be concluded with the inferences drawn from the study.

\footnotetext{
Authors' contributions

SS, the first author is responsible for the design and structure of the study. Data collection, interpretation, analysis and manuscript writing is the work of the first author. Dr. IS, the second author provided the intellectual inputs, investigated the design of the study and supervised the preparation of manuscript. Both authors read and approved the final manuscript.

\section{Acknowledgements}

The authors are grateful to MMRDA for providing data and allowing the usage of the documents for analysis.
} 


\section{Competing interests}

The authors declare that they have no competing interests (financial and non-financial).

\section{Availability of data and materials}

The results obtained in this study are derived from the analysis of the Mumbai Metropolitan Region's Regional Plans 1996-2011. The plans are available online on the Mumbai Metropolitan Region Development Authority's website. The satellite images were downloaded from the public domain of USGS (https ://earthexplorer.usgs.gov/)

\section{Consent for publication}

The authors give their full consent for the publication of this manuscript in the Springer Journal City, Territory and Architecture.

\section{Ethics approval and consent to participate}

Not applicable.

\section{Funding}

This study was financially supported by MEXT (Monbukagakusho) and JSPS KAKENHI Grant Number 16H03311 in conducting the field surveys. However, there is no role of the funding bodies in design of the study and collection, analysis, interpretation of data or in manuscript writing.

\section{Publisher's Note}

Springer Nature remains neutral with regard to jurisdictional claims in published maps and institutional affiliations.

Received: 21 November 2017 Accepted: 25 July 2018

Published online: 01 August 2018

\section{References}

Antonson H, Isaksson K, Hjerpe M, Storbjark S (2016) Negotiating climate change responses: regional and local perspective on transport and coastal zone planning in South Sweden. Land Use Policy. https://doi. org/10.1016/j.landusepol.2015.12.033

Baettig M, Wild M, Imboden D (2007) A Climate Change Index: where climate change may be most prominent in the 21st century. Geophys Res Lett. https://doi.org/10.1029/2006gl028159

Baynham M, Stevans M (2012) Are we planning effectively for climate change? An evaluation of official community plans in British Columbia. J Environ Plan Manag 57(4):557-587

Biesbroek R, Swart R, Knaap W (2009) The mitigation adaptation dichotomy and the role of spatial planning. Habitat Int. https://doi.org/10.1016/j. habitatint.2008.10.001

Biesbroek GR et al (2010) Europe adapts to climate change: comparing national adaptation strategies. Glob Environ Change 20(3):440-450

Boswell MR, Greve Al, Seale TL (2012) Local climate action planning, 1st edn. Island press, Washington DC

Census 2011 (2011) City Census 2011. http://www.census2011.co.in/city.php. Accessed 23 July 2017

Census Data (2011) A-4 towns and urban agglomerations classified by population size class in 2011 with variation since 1901, Ministry of Home Affairs, Government of India, Delhi. http://www.censusindia.gov.in/2011 census/ PCA/A4.html. Accessed 20 July 2017. Accessed 17 June 2017

Chang M, Dereczynski C, Freitas M, Chou S (2014) Climate Change Index: a proposed methodology for assessing susceptibility to future climatic extremes. Am J Clim Change. https://doi.org/10.4236/ajcc.2014.33029

City and Industrial Development Corporation of Maharashtra Limited (CIDCO) (1973) Navi Mumbai Draft Development Plan, (October 1973), Mumbai

City of London (2017) London, canada: The official website of city of London. https://www.london.ca/residents/Environment/Climate-Change/Pages/ Reducing-Greenhouse-Gas-Emissions.aspx. Accessed 5 Dec 2017

Conroy MM, Berke PR (2004) What makes a good sustainable development plan? An analysis of factors that influence principles of sustainable development. Environ Plan A 36(1):1381-1396
Cropper M, Bhattacharya S (2012) Public transport subsidies and affordability in Mumbai, India. Hindawi Publishing Corporation, Cairo. https://doi. org/10.1155/2012/865972

Das A, Parikh J (2004) Transport scenarios in two metropolitan cities in India: Delhi and Mumbai. Energy Convers Manag 45:2603-2625. https://doi. org/10.1016/j.enconman.2003.08.019

Davoudi S, Crawford J, Mehmood A (2009) Planning for climate change: strategies for mitigation and adaptation for spatial planners. Earthscan Publishers, Sterling

Davoudi S et al (2012) Resilience: a bridging concept or a dead end? "Reframing" resilience: challenges for planning theory and practice interacting traps: resilience assessment of a pasture management system in Northern Afghanistan urban resilience. Plan Theory Pract 13(2):299-333

DES (2016) Directorate of Economics and Statistics, Planning Department, Government of Maharashtra. Economic Survey of Maharashtra 2016-2017, Mumbai

DNA (2009) Daily news and analysis. Mumbai is India's city with the greatest inequalities. http://www.dnaindia.com/mumbai/report-mumbai-is-india -s-city-with-the-greatest-inequalities-1306460. Accessed 1 Sept 2017

Dutt AK, Costa FJ, Aggarwal S (1994) The Asian City: process of development, characteristics and planning. Kluwer Academic Publishers, Dordrecht

EPA (2016) Climate change adaptation resource center (ARC-X). Planning for climate change adaptation. https://www.epa.gov/arc-x/planning-clima te-change-adaptation. Accessed 22 July 2017

Füssel H-M (2007) Adaptation planning for climate change: concepts, assessment approaches, and key lessons. Sustain Sci 2(2):265-275

Greater London Authority (2011) Delivering London's energy future. Greater London Authority, City Hall

Hamin E, Gurran N (2009) Urban form and climate change: balancing adaptation and mitigation in the US and Australia. Habitat Int. https://doi. org/10.1016/j.habitatint.2008.10.005

Hoornweg D, Sugar L, Gómez CLT (2011) Cities and greenhouse gas emissions: moving forward. Environ Urban 23(1):207-227

Hurlimann AC, March AP (2012) The role of spatial planning in adapting to climate change. WIREs Clim Change 3(5):477-488

Kamal-Chaoui L, Robert A (2009) Competitive cities and climate change. OECD, Paris

Kumar R, Jawale P, Tandon S (2008) Economic impact of climate change on Mumbai, India. Reg Health Forum 12(1):38-42

Kumar S, Bhattacharyya JK, Vaidya AN, Chakrabarti T, Devotta S, Akolkar AB (2009) Assessment of the status of municipal solid waste management in metro cities, state capitals, class I cities and class II towns in India: an insight. Waste Manag 29(2):883-895

Measham TG et al (2011) Adapting to climate change through local municipal planning: barriers and challenges. Mitig Adapt Strat Glob Change 16(8):889-909

MMRDA (1996a) Mumbai Metropolitan Region Development Authority. Regional plan for MMR, 1996-2011. Part 1-Chapter 2 Regional Settings, Mumbai

MMRDA (1996b) Mumbai Metropolitan Region Development Authority. Regional plan for MMR, 1996-2011. Part 3-Chapter 15, Development Control Regulations for Mumbai Metropolitan Region, 1999, Mumbai

MMRDA (2017) Mumbai Metropolitan Region Development Authority. Draft Regional Plan for MMR 2016-2036, Mumbai

MMRDA Act (1974) Mumbai Metropolitan Region Development Authority Act. Maharashtra Act No IV of 1975, Law and Judiciary Department, Government of India

Norton R (2008) Using content analysis to evaluate local master plans and zoning codes. Land Use Policy 25:432-454. https://doi.org/10.1016/j.landu sepol.2007.10.006

Parliamentary Office of Science and Technology-UK (2006) Adapting to climate change in developing Countries, October 2006. http://www. fesghana.org/uploads/PDF/UKparliament_2006_adapting\%20to\%20cli mate\%20change\%20in\%20developing\%20countries.pdf. Accessed 22 July 2017

Patil A, Shekdar A (2001) Health-care waste management in India. J Environ Manag 63(2):211-220

Ramachandra T, Shwetmala (2009) Emissions from India's transport sector: statewise synthesis. Atmos Environ. https://doi.org/10.1016/j.atmos env.2009.07.015 
Ramachandra T, Sreejith K, Bharath H (2014) Sector-wise assessment of carbon footprints across major cities in India, vol 2. EcoProduction. Springer, Singapore. https://doi.org/10.1007/978-981-4585-75-0_8

Raparthi K (2014) Impact of urban planning policies on carbon-dioxide emissions: an Indian perspective, PhD, The University of Texas at Arlington

Recent Natural Disasters (2016) List of natural disasters in India. Disaster report. http://www.disaster-report.com/2016/01/list-of-natural-disasters-in-india -2016.html. Accessed 22 July 2017

Roggema R (2016) The future of sustainable urbanism: a redefinition. City Territ Archit 3(22):12

Stevens M (2013) Evaluating the quality of official community plans in Southern British Columbia. J Plan Educ Res. https://doi.org/10.1177/07394 $56 \times 13505649$

Tang Z, Lindell M, Prater C, Wei T, Hussey CM (2011) Examining local coastal zone management capacity in US Pacific Coastal Counties. Coast Manag 39:105-132. https://doi.org/10.1080/08920753.2010.540708

Tang Z, Dai Z, Fu X, Li X (2013) Content analysis for the US coastal states' climate action plans in managing the risks of extreme climate events and disasters. Ocean Coast Manag 80:46-54. https://doi.org/10.1016/j.oceco aman.2013.04.004

Taylor R (2012) Urbanization, local government and planning for sustainability. In: Weinstein MP, Turner RE (eds) Sustainability science: the emerging paradigm and the urban environment. Springer, Berlin. https://doi. org/10.1007/978-1-4614-3188-6_14

The Guardian (2014) Mumbai will likely flood again- and nobody's dong much about it, November 2014. https://www.theguardian.com/cities/2014/ nov/27/mumbai-flood-rain-monsoon-city-planning. Accessed 23 July 2017

The World Bank (2010) Cities and climate change: an urgent agenda. The World Bank, Washington DC

The World Bank (2011) Cities and climate change: responding to an urgent agenda. The World Bank, Washington DC

Times of India (2012) One in 10 properties in the city lying vacant. http://times ofindia.indiatimes.com/city/mumbai/One-in-10-properties-in-city-lying -vacant/articleshow/12285400.cms. Accessed 1 Sept 2017
Times of India (2017) Spectaculars lock up nearly 13 lack flats in housing starved Mumbai region. http://timesofindia.indiatimes.com/city/mumba i/speculators-lock-up-nearly-13-lakh-flats-in-housing-starved-mumba i-region/articleshow/56284157.cms. Accessed 1 Sept 2017

United Nations Human Settlement Programme (UN-Habitat) (2014) Planning for climate change: a strategic, value based approach for urban planners (HS/001/14E). United Nations Human Settlements Programme (UN Habitat), Nairobi

United Nations (2016) The World's Cities in 2016. http://www.un.org/en/devel opment/desa/population/publications/pdf/urbanization/the_world s_cities_in_2016_data_booklet.pdf. Accessed 19 Sept 2017

United Nations, Department of Economic and Social Affairs, Population Division (2015a). World population prospects: the 2015 revision, key findings and advance tables. Working Paper No. ESA/P/WP.241

United Nations, Department of Economic and Social Affairs, Population Division (2015b). World urbanization prospects: the 2014 revision, (ST/ESA/ SER.A/366)

Wahlgren I, Barrett P, Amaratunga D, Haigh R, Keraminiyage K, Pathirage C (2010) Climate change and urban planning. https://www.researchga te.net/publication/47524996_Climate_change_and_urban_planning. Accessed 25 Sept 2017

Waldner LS (2004) Planning to perform: evaluation models for city planners. UC Berkeley Plan J 17(1):1-28

Wilson E, Piper J (2010) Spatial planning and climate change. Routledge, London

World Bank Data (2017) Fossil fuel energy consumption (\% of total). http:// data.worldbank.org/indicator/EG.USE.COMM.FO.ZS. Accessed 25 July 2017

York C. o. N. (2017) Mayor announces dramatic drop in energy use and carbon emissions in large buildings citywide. https://www1.nyc.gov/offic e-of-the-mayor/news/663-17/mayor-dramatic-drop-energy-use-carbo n-emissions-large-buildings-citywide. Accessed 12 Apr 2018

Young AF (2016) Adaptation actions for integrated climate risk management into urban planning: a new framework from urban typologies to build resilience capacity in Santos (SP). City Territ Arch 3(12):17

\section{Submit your manuscript to a SpringerOpen ${ }^{\circ}$ journal and benefit from:}

- Convenient online submission

- Rigorous peer review

- Open access: articles freely available online

- High visibility within the field

- Retaining the copyright to your article

Submit your next manuscript at $\boldsymbol{\nabla}$ springeropen.com 